\title{
DO THE DISTRIBUTION OF ZAKAT AND ISLAMIC BANK FINANCING AFFECT INCOME INEQUALITY IN INDONESIA?
}

\author{
Al Haq Kamal ${ }^{1}$, Ratih Purbowisanti ${ }^{2}$, Ageng Asmara Sani ${ }^{3}$, Kusumaningdyah Retno \\ Setiorini ${ }^{4}$ \\ ${ }^{1234}$ Universitas Alma Ata, Jl. Brawijaya No.99, Jadan, Tamantirto, Kec. Kasihan, Bantul, \\ Daerah Istimewa Yogyakarta \\ 1kamal.alhaq@almaata.ac.id, 2ratihp33@gmail.com, ${ }^{3}$ agengasmara@almaata.ac.id, \\ k.retno.s@almaata.ac.id
}

\begin{abstract}
This study aims to reveal empirically the extent to which Islamic economics contributes to Indonesia's economic equality. This study uses zakat distribution indicators and financing of Islamic banks as an instrument of income distribution in Islamic economics; GINI coefficients are indicators for measuring income inequality and using panel data with a cross-section of 12 provinces in Indonesia the 2011-2016 period. This study found that the distribution of zakat has a negative effect on income inequality and Islamic bank financing has a positive effect on income inequality.
\end{abstract}

Keywords: Zakat, Islamic Banking, Income Inequality

\section{Introduction}

Islamic economists believe that the Islamic economic system's application can build the benefit of society in the context of efficient and equitable economic development (Chapra, 2000) (Zaman, 2019) (Kholik, N., Ismiati, B., \& Balqish, 2019) (Salam \& Risnawati, 2019). Islamic economics normatively has various instruments that create a just economy such as zakat, waqf, and Islamic banking. Efficiency and equity are goals that are aspired in the economic order. However, statistical data shows that the Gini coefficient in various countries with Muslim populations is between 30 and 50 (Muttaqin, 2013). it can represent that income inequality in Muslim countries is relatively high.

According to WorldCat CIA data, Indonesia's income inequality ranks 86th, while according to World Bank Indonesia, data ranks 68th. In the first semester of 2011, Indonesia's income inequality reached 0.410 for the first time until the peak reached 0.414 in the second semester of 2014. In 2017 level Indonesia's inequality shows a downtrend reaching 0.391. Simultaneously, various sectors of the Islamic economy in Indonesia experienced developments such as an increase in zakat distribution, the growth of financial services, and Islamic banking. 
Graphic 1

Indonesia GINI Ratio 2010 to 2017

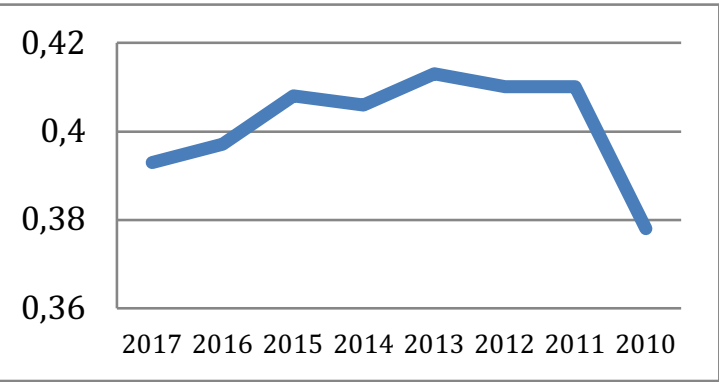

Source: Indonesian Statistic Bureau

Islāmic teachings direct can distribute production resources equitably, to not accumulate in particular groups in society. These conditions encourage fair economic equality (Hafidhuhhin, 2008a) (Michalopoulos, 2016). In terms of economic development, zakat plays an instrument of the income distribution (Mansoor, 2016) (Hafidhuddin, 2002). On the other hand, the capitalist economic system only emphasizes economic growth or national income to create an unfair distribution pattern of wealth (Rahmawaty, 2010) (Bos, 2018). Empirical facts found by researchers that zakat has been welldistributed to mustahiq can reduce the level of income inequality Beik, 2009) (Ismail \& Possumah, 2013) (Mu'inan, 2011) So that the role of zakat in a country's economy needs to be optimized to create a fair economy.
Graphic 2

Growth of ZIS Collection 2002 to 2016

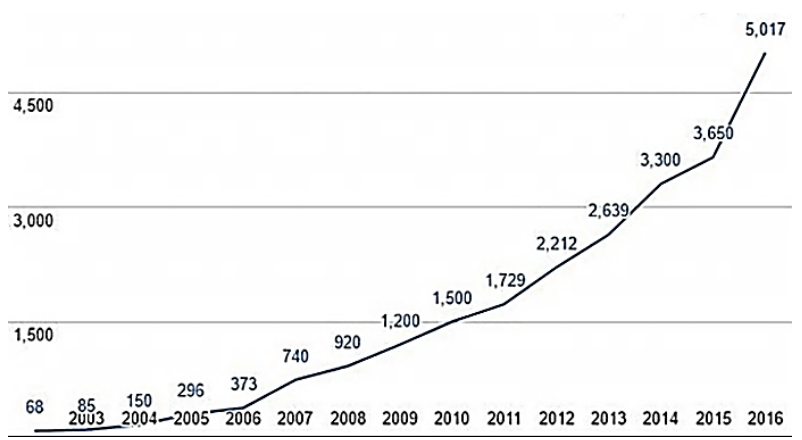

Source: National Zakat Statistics 2016

The growth of zakat collection in Indonesia is growing quite rapidly. Especially after the passage of the Law on the management of zakat in 2011. In 2011 the realization of national zakat reached IDR 1.72 Trillion, growth reached $15.27 \%$ from the previous year. In 2016, zakat realization's change came $37.46 \%$ with a realization value of IDR 5.01 trillion (Widiastuti, 2018) (Rusny Istiqomah Sujono, 2017) (Rifatunisa, 2019).

The researcher wants to empirically prove how the theory of Islamic economists who argue that the application of the Islamic economic system can provide benefits for the community. Using zakat distribution indicators and Islamic bank financing as an instrument of income distribution in the Islamic economy, the GINI coefficient indicates income inequality. 


\section{Literature Review}

\section{Research on Zakat and Inequality Income}

Nova Rini examined the role of zakat in reducing income inequality and poverty. The indicators used are the Lorenz Curve, Gini Coefficient, Income Gap Index, Sen Index, FGT Index, and others(Rini, Huda, \& Mardoni, 2013). The study found that the study results showed that zakat reduced income inequality by an average of 0.3 percentage points. So that income inequality is reduced by $27 \%$.

Further research literature Aprianto in his research states that the concept of distribution in Islamic economics focuses on eliminating usury. Then, the public is demanding to be aware of the importance of creating fairness of distribution and narrowing economic inequality through zakat and Sukuk (Aprianto, 2016).

Beik examined the impact of zakat in reducing poverty in 50 samples. The poverty depth index is measured using two tools: the poverty gap ratio $(\mathrm{P})$ as an indicator of the poverty gap and the income-gap rate (I) as an income gap indicator. Beik concluded that zakat could reduce the income gap (Beik, 2009).

Ismail et al. (2013) Zakat can help minimize the poor's debt and reduce the unequal distribution of wealth in society. The same result found by Ayuniyyah where
Zakat can significantly reduce poverty and reduce income inequality mustahiq (Ayuniyyah, Pramanik, \& Saad, 2018)

Research on Banking Financing and Income Inequality

Madhu Sehrawat analyzed the relationship between financial development and rural-urban income inequality in the South Asian Association for Regional Cooperation Countries (SAARC) using panel data from 1986-2012. This research indicates that financial development increases income inequality in rural-urban areas (Sehrawat \& Giri, 2018).

Another study on the relationship between Islamic banking financing and income inequality is Purwanto, which states that the distribution of financing by Islamic banking impacts people's income differentials (Purwanto, 2017). By using panel data regression data, it concluded that the financing carried out by Commercial Banks and Sharia Business Units aimed at positive \& significant results affecting the level of differences in community income.

Hidayat examines the role of Islamic banks in improving the distribution of people's welfare. This study indicates that the distribution of Islamic bank financing has a positive effect on the Gini ratio (Hidayat \& Surahman, 2017). (Buhaerah, 2017) examines the impact of financialization on income distribution in 
ASEAN using panel data from 1990 to 2013.

The research proves that financialization had positively correlated with income distribution. This means that the level of financialization increases the level of income inequality.

While Afandi examines the impact of economic structure changes, financialization, and social conditions on Indonesia's income inequality. Using panel data on 32 provinces in Indonesia in 20072013. This study found that financialization negatively influences the financialization hypothesis (Afandi \& Rantung, 2017).

\section{Research Methods}

This study uses panel data with an annual period from 2011 to 2016 to measure zakat distribution and Islamic banking financing on income inequality. The indicators used in this study are the distribution of zakat and the distribution of Islamic bank financing funds in Indonesia. The indicator of income distribution used in this study is the Gini coefficient. Gini coefficient data obtained from the Indonesian Central Statistics Agency. Data on Islamic banking financing obtained from Islamic Banking statistics. Zakat distribution data obtained from the annual report of Baznas. Twelve provinces have complete data, including Gini coefficient data, Islamic bank financing data, and zakat distribution. So the regions that fulfill the data completeness requirements in this study are the Provinces, South Sumatra, West Sumatra, Banten, Bangka Belitung, West Java, DKI Jakarta, Central Java, South Kalimantan, East Kalimantan, Gorontalo, North Sulawesi

After the data is collected, the analysis performed with a panel data regression model. Panel data is a combination of time series data and cross-section. By accommodating information related to cross-section variables and time series, panel data is substantially able to provide more data so that it will result in greater degrees of freedom and be able to overcome problems caused by ignoring relevant variables (Omitted-Variables) ) (Widarjono, 2013a). Several methods are commonly used to estimate regression models with panel data, namely the Common Effect, Fixed Effect, and Random Effect approaches (Sriyana, 2014).

\section{Common Effect}

This approach is the simplest technique for estimating panel data, only by combining time-series data and cross-sections. By combining data without seeing the differences between time and individuals. So it is assumed that data between companies is the same in various periods. following the regression model:

$$
\text { Yit }=\beta 0+\beta 1 X 1 \text { it }+\beta 2 X 2 i t+\text { eit }
$$

Information:

Yit : The value of the Gini ratio of the $i$ 
region of the t-year

$\beta 0 \quad$ : Constant

$\beta 1 X 1$ it : Distribution value of zakat in the i-th region t-year

$\beta 2 X 2$ it : Value of Islamic banking financing in the i-th region t-year

eit : Residual value of the region $\mathrm{i}$-th year $\mathrm{t}$

\section{Fixed Effect}

This method assumes that the research object has a different intercept but has the same slope. An individual or company has the same intercept for each time difference and the constant-coefficient from time to time (time-variant) (Widarjono, 2013b).

In the fixed-effect approach, the dummy variable technique used to explain the differences in the intercepts. The regression model written as follows:

$$
\begin{aligned}
\text { Yit } & =\beta 0+\beta 1 X 1 i t+\beta 2 X 2 i t+\beta 5 D 1 i+\beta 4 D 2 i \\
& +\beta 7 D 3 i+\beta 5 D 3 i+\beta 6 D 4 i \text { i }+\beta 7 D 5 i+ \\
& \beta 8 D 6 i+\beta 9 D 7 i+\beta 10 D 8 i+\beta 11 D 9 i+ \\
& \beta 12 D 10 i+\beta 13 D 11 i+\beta 14 D 12 i+e i t
\end{aligned}
$$

Information:

Yit : the value of the Gini ratio of the I region of the t-year

$\beta 0 \quad$ : constant

$\beta 1 X 1$ it : distribution value of zakat in the i-th region t-year

$\beta 2$ X2it : value of Islamic banking financing in the $\mathrm{i}$-th region $\mathrm{t}$-year

$\beta 3 \mathrm{D} 1 \mathrm{i}: 1$ for West Sumatra Province and
0 for other provinces

$\beta 4$ D2i : 1 for South Sumatra Province and

0 for other provinces

$\beta 5$ D3i : 1 for Bangka Belitung Province and 0 for other provinces

36D4i : 1 for DKI Jakarta Province and 0 for other provinces

$\beta 7$ D5i : 1 for West Java Province and 0 for other provinces

$\beta 8$ D6i : 1 for Central Java Province and 0 for other provinces

$\beta 9 D 7 i$ : 1 for East Java Province and 0 for other provinces

$\beta 10 D 8 i$ : 1 for Banten Province and 0 for other provinces

$\beta 11 D 9 i$ : 1 for South Kalimantan Province and 0 for other provinces

312D10i: 1 for East Kalimantan Province and 0 for other provinces

313D11i $\quad: 1$ for North Sulawesi

Province and 0 for other provinces

B14D12i $\quad: 1$ for Gorontalo Province

eit and 0 for other provinces : residual value of the region $\mathrm{i}$-th year $\mathrm{t}$

\section{Random Effect}

This approach does not use dummy variables but uses residuals suspected to have intertemporal and interindividual / inter-company relationships. The random effect model assumes that each variable has a random intercept difference. 


$$
\text { Yit }=\beta 0 \mathrm{i}+\beta 1 \mathrm{X} 1 \mathrm{it}+\beta 2 \mathrm{X} 2 \mathrm{it}+\mathrm{et}
$$

Information:

Yit : the value of the Gini ratio of the $\mathrm{i}$ region of the t-year

$\beta 1 X 1$ it : distribution value of zakat in the i-th region t-year

$\beta 2 X 2$ it : value of Islamic banking financing in the i-th region t-year

et $\quad: t$-year residual values

In this approach, $\beta 0 \mathrm{i}$ is no longer fixed (nonstochastic) but is random. Because of the relationship between disturbance variables in this random effect equation, the OLS method cannot get a good estimator. The right method used to estimate the random effect model is GLS.

\section{Panel Data Regression Estimation}

\section{Techniques}

Choosing a model for estimating can do panel data regression in two ways. Informally the selection can be made based on specific considerations. As conducted by Judge regarding the fundamental differences to determine the choice between fixed effects and random effects approaches, namely (Gujarati \& Porter, 2016):

If $\mathrm{T}$ (number of time series data) is large and $\mathrm{N}$ (number of cross-section data) is small, there will be a slight difference in the estimated value of the parameter between fixed effects and random effects. In this case, the fixed effect might be preferred.
When $\mathrm{N}$ is greater than $\mathrm{T}$, a random effect is more suitable if the sample unit's crosssection is random. Meanwhile, if we are sure and believe that the individual/cross section of the sample is not random, then the fixed effect is more suitable for use.

If the individual error component $\mu \mathrm{i}$ and one or more independent variables are correlated, the random effect estimation will be biased, while the fixed effect is not biased.

If $\mathrm{N}$ is large and $\mathrm{T}$ is small, and if the random effect's assumptions are met, then the random effect is more efficient than the fixed effect.

While formally selecting estimates, three testing procedures can be used: the $\mathrm{F}$ statistical test, the Langrange Multiplier test, and the Hausman test.

\section{Chow Test}

This test used to choose between a common effect and fixed effect approach. We will determine whether the panel data regression technique using fixed effects is more appropriate than using the commoneffect. The null hypothesis is that the common-effect model is better than the fixed-effect provided that if Fcount $>$ Ftable, then Ho is rejected. If Fcount $<$ Ftable, then Ho is accepted. If the results of the chow test state that Ho is accepted, then the panel data regression technique uses the pool model (common effect), and the test stops here. If 
the results of the chow test state that Ho is rejected, then the panel data regression technique uses the fixed-effect model, and the Hausman Test is performed.

\section{Hausman Test}

Hausman test was used to choose between fixed effect and random effect models. This Hausman test statistic follows the distribution of chi-squares statistics with degrees of freedom as many ask, where $\mathrm{k}$ is the number of independent variables. The null hypothesis is that the random effect model is better than the fixed effect, provided that if the Hausman statistical value is $>$ the critical value, Ho is rejected. If the Hausman statistical value is $<$ critical value then Ho is accepted.

\section{Langrange Multiplier Test}

This test was used to choose between the common-effect and random effect models. The null hypothesis is that the commoneffect model is better than the random effect, provided that if the LM statistical value $>$ the critical value of the chi-squares statistic, then Ho is rejected. If the statistical value of $\mathrm{LM}<$ the chi-squares statistic's critical value, then Ho is accepted.

\section{Discussion}

This study analyzed 48 observations consisting of 12 provinces in Indonesia during the 2012-2013 period. The analysis begins by testing the three-panel data analysis models: common effects, fixed effects, and random effects. The results of all three tests shown in the following table:

Table 1

Estimation Results of common effects, fixed effects and random effects models

\begin{tabular}{|c|c|c|c|c|c|c|}
\hline & Com & non & Fixe & & Ranc & om \\
\hline Inde & Effec & & Effec & & Effec & \\
\hline pen & Mod & & Mod & & Mod & \\
\hline dent & Coe & & Coe & & Coe & \\
\hline Vari & ffici & Pro & ffici & Pro & ffici & Pro \\
\hline able & ent & $b$ & ent & $\mathrm{b}$ & ent & $b$ \\
\hline & & & & 0.0 & & 0.0 \\
\hline & 201 & 0.0 & 202 & 00 & 201 & 00 \\
\hline GIN & 5.1 & 000 & 4.2 & $0^{*}$ & 5.1 & $0^{*}$ \\
\hline I & 10 & $* *$ & 82 & $*$ & 10 & $*$ \\
\hline & - & & - & 0.0 & - & 0.0 \\
\hline & 7.3 & 0.0 & 33. & 00 & 7.3 & 22 \\
\hline Zak & 054 & 522 & 159 & $3 *$ & 054 & $9 *$ \\
\hline ah & 82 & $* *$ & 44 & $*$ & 82 & $*$ \\
\hline & & & & 0.0 & & 0.0 \\
\hline & 0.5 & 0.0 & 0.7 & 00 & 0.5 & 00 \\
\hline & 351 & 000 & 264 & $0 *$ & 351 & $0^{*}$ \\
\hline IF & 55 & $* *$ & 67 & $*$ & 55 & $*$ \\
\hline Adj & & & & & & \\
\hline uste & & & & & & \\
\hline d R- & 0.3 & & 0.5 & & 0.3 & \\
\hline squa & 497 & & 321 & & 497 & \\
\hline red & 41 & & 52 & & 41 & \\
\hline
\end{tabular}


Pro

$\mathrm{b}$

$\begin{array}{llll}(\mathrm{F}- & 0.0 & 0.0 & 0.0 \\ \text { stati } & 000 & 000 & 000 \\ \text { stic }) & 02 & 02 & 02\end{array}$

To determine which model is the best, a test is made by comparing estimation models. Table 2 compares the common and fixed effects models:

Table 2

Chow Test: Common dan Fixed Effects

Redundant Fixed Effects

Tests

Equation: Untitled

Test cross-section fixed effects

Effects Test Statistic d.f. Prob.*

Cross-section F $3.020353(11,46) 0.0042$

Cross-section

Chi-square $\quad 32.61818811 \quad 0.0006$

Note: Ho: common-model is a true model; Ha: the fixed effects model is correct. $*=\mathrm{Ho}$ is rejected at $\alpha=1 \%$. This means that the fixed-effects model is better than the common-model.

The table above shows that the p-value in the chi-square cross-section is $0.0042<\alpha=$ 0.01 , so $\mathrm{HO}$ is rejected, which means it is better to use the fixed-effect the commoneffect model.
Table 3

Hausman Test: Fixed dan Random Effects

Correlated Random Effects -

Hausman Test

Equation: Untitled

Test cross-section random effects

\begin{tabular}{llll}
\hline \hline & \multicolumn{3}{c}{ Chi- } \\
& Chi-Sq. & Sq. & \\
Test Summary & Statistic & d.f. & Prob. ${ }^{*}$ \\
\hline \hline Cross-section & & & \\
random & 33.2238882 & 0.0000 \\
\hline \hline
\end{tabular}

Note: Ho: random-effects is a true model; Ha: fixed effects model is correct. $*=$ Ho is rejected at $\alpha=5 \%$. This means that the fixed effects model is better than the randomeffects model.

The table above shows a p-value of $0.0000<\alpha=0.05$, which means that $\mathrm{H} 0$ is not rejected, so the Fixed effect model is better used. Based on the model's testing, it was found that the best model in this analysis was the fixed effects model. In table 1, information obtained that part, the variables that significantly affect the inequality of income distribution (Gini ratio) are zakat distribution and Islamic bank financing.

Zakat distribution variable has a negative impact on the Gini ratio. This means that zakat distribution is a potential for increasing regional income. The distribution of zakat to the Muslim community, 
accompanied by productive zakat management, will positively contribute to regional economic development, reducing income inequality. These findings confirm the research (Rini et al., 2013) (Beik, 2009); (Ismail \& Possumah, 2013) and (Safitri, 2019) that found that zakat distribution can reduce income inequality.

Zakat has a goal to support the poor consumptively and has a primary goal, namely poverty alleviation (Hafidhuhhin, 2008b). Zakat will prevent the accumulation of wealth in the hands of a small number of people. People who have more funds or are said to be capable of giving a certain amount of assets to those in need or deficient. Thus, zakat is a social security instrument tasked with bridging the transfer of wealth from the rich to the poor (Beik, 2009).

This study's results are consistent with the research results (Hidayat \& Surahman, 2017) that financing by Islamic banking has a positive effect on income inequality. This means that the higher the financing channeled by Islamic banking will increase income inequality. This finding confirms Hidayat's (2017) findings and Buhaerah (2017) opinion on financing, which positively affects income inequality. According to Hidayat (2017), most financing undertaken by Islamic banking aimed at the consumption sector will not increase business opportunities and increase public income. This type of financing will reduce people's income because they have to pay margins to compensate for the financing. This kind of situation will create a level of inequality in the community.

Graphic 3

\section{Distribution of Islamic Bank Financing in Indonesia 2016}

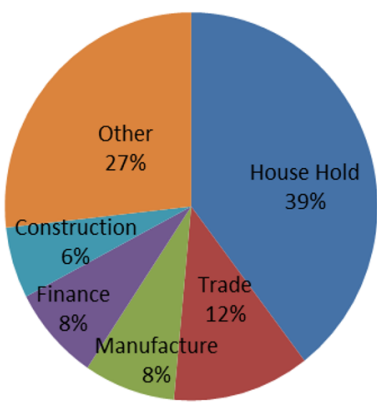

Source: Sharia Financial Development

Report 2016

The sharia financial development report above shows that the most considerable portion of financing channeled to the household consumption sector, namely $40.06 \%$, followed by wholesale and retail trade at $12.06 \%$, financial intermediaries with a share of $7.46 \%$, construction with a share of $5.64 \%$, and the processing industry at $7.97 \%$. Suppose the portion of financing channeled to productive sectors such as MSMEs, manufacturing, construction, wholesale trade, and retail is more than that of households. In that case, Islamic banking financing will increase income, which will reduce the income gap. 
Financing carried out by Islamic banking in Indonesia can increase income disparity due to economic financialization. (Buhaerah, 2017) Financialization is the domination of the financial sector's role rather than real economic activity in the economy, both at the domestic economy level and the global economic level. Economic financialization can increase disparities, according to Stockhammer, because an increase in financial sector income, in this case, is the determination of margins (Stockhammer, 2010). Profits for Islamic banking can be guaranteed because of the conclusion of margins, while financing recipients may not necessarily increase their income. More distribution in the household sector will further increase capital owners' income, in this case, Islamic banking. On the other hand, people who receive financing cannot raise their revenue.

This study's results also confirm the research conducted by (Clarke, $\mathrm{Xu}, \& \mathrm{Zou}$, 2003) and (Liang \& Jian-Zhou, 2006). They found a linear relationship between the financial system and income loss. Inequality can increase in line with increased development in the financial sector and the financial sector's low development level. This is consistent with the statement put forward by Greenwood and Jovanovic, which shows how financial and economic development can lead to an inverse relationship. U-shaped relationship between income inequality and financial sector development (Greenwood \& Jovanovic, 1990).

The discussion consisted of a foundation of literature theory/study, discussion of research result, and analysis. The number of words in the discussion maximum 2500 words.

\section{Conclusion}

This study empirically reveals the extent to which the Islamic economy contributes to reducing income inequality in Indonesia. This study uses panel data with a crosssection of 12 provinces in Indonesia and 2012-2016. This study found that the distribution of zakat has a negative effect on income inequality. Then the researchers found that Islamic bank financing has a positive effect on income inequality. This means that the higher the financing channeled by Islamic banking, the higher the income inequality is. The argument for this phenomenon is that most of the portion of Islamic banking financing aimed at the consumption sector to increase business fields and increase people's income.

The study results indicate that Islamic bank financing in Indonesia can cause inequality in people's income. This is because the distribution of financing dominated the household sector or the 
consumptive sector. Financing in the consumptive sector can ultimately increase disparity because financing with this pattern is only the capital owner who gets a substantial profit by determining the margin. In contrast, the community receiving financing cannot increase their income. To overcome this problem, the government should control the financing patterns carried out by Islamic banking. The Islamic banking sector must also increase financing in productive sectors such as MSMEs, manufacturing, construction and wholesale trade, and retail, which is more than the household portion. Will increase income, which in turn will reduce the income gap.

\section{Reference}

Afandi, A., \& Rantung, V. (2017). Determinants of income inequality. Economic Journal of emerging markets, 159-171. doi: 10.20885/ejem.vo19.iss2.art5

Aprianto, N. (2016). Kebijakan Distribusi dalam Pembangunan Ekonomi Islam. Al-Amwal: Jurnal Ekonomi dan Perbankan Syari'ah, 8(2). doi: http://dx.doi.org/10.24235/amwal.v8i 2.990

Ayuniyyah, Q., Pramanik, A., \& Saad, N. (2018). Zakat For Poverty Alleviation And Income Inequality Reduction: West Java, Indonesia. Journal of
Islamic Monetary Economics and Finance, 4(1).

Beik, I. (2009). Analisis Peran Zakat Dalam Mengurangi Kemiskinan: Studi Kasus Dompet Dhuafa Republika. Jurnal Pemikiran Dan Gagasan.

Bos, K. V. D. (2018). Self-Interest and Insufficient Corrections: Oxford University Press.

Buhaerah, P. (2017). Influence of financialization of income inequality in ASEAN: Data panel analysis. Buletin Ekonomi Moneter dan Perbankan.

Chapra, U. (2000). Islam dan Tantangan Ekonomi, alih bahasa Ikhwan Abidin Basri Jakarta: Gema Insani Press, Tazkiah Institute.

Clarke, G., Xu, L., \& Zou, H. (2003). Finance and income inequality: Test of alternative.

Greenwood, J., \& Jovanovic, B. (1990). Financial Development, Growth, and the Distribution of Income. Journal of Political Economy, 98(05).

Gujarati, D., \& Porter, D. (2016). DasarDasar Ekonometrika terjemahan.

Hafidhuhhin, D. (2008a). Zakat dalam Perekonomian Modern Jakarta: Gema Insani

Hafidhuhhin, D. (2008b). Zakat dalam Perekonomian Modern Cet-7. 
Hidayat, Y., \& Surahman, M. (2017). Analisis Pencapaian Tujuan Bank Syariah Sesuai Uu No 21 Tahun 2008. Amwaluna : Jurnal Ekonomi dan Keuangan Syariah, 1(1), 34-50. doi: http://doi.org/10.29313/amwaluna.v1i 1.1996

Ismail, A., \& Possumah, B. (2013). Theoretical Model For Zakat-Based Islamic Microfinance Institutions In Reducing Poverty. International Research Journal of Finance and Economics(1).

Kholik, N., Ismiati, B., \& Balqish, N. (2019). Analisis Program Peningkatan Kesejahteraan Masyarakat di Rumah Zakat Yogyakarta. Ideas: Jurnal Pendidikan, Sosial, Dan Budaya, 4(4), 631-652.

https://jurnal.ideaspublishing.co.id/in dex.php/ideas/article/view/137

Liang, Q., \& Jian-Zhou, T. (2006). Financial development and economic growth: Evidence from China. China economic review.

Mansoor, A. (2016). Efficiency and justice in income distribution - necessary and sufficient conditions and the Islamic economic model. Journal of King Abdulaziz University, Islamic Economics, 29(3), 1-26. DOI: 10.4197/Isles.29-3.5
Michalopoulos, S. (2016). Islam, inequality, and pre-industrial comparative development. Journal of Development Economics, 120, 86-98. DOI: 10.1016/j.jdeveco.2016.01.002

Mu'inan. (2011). Potensi Zakat (dari Konsumtif-Kreatif ke ProduktifBerdayaguna) Perspektif Hukum Islam. Citra Pustaka.

Muttaqin, H. (2013). Tinjauan Ketimpangan Ekonomi di Negeri-Negeri Islam. Paper presented at the Jakarta International Conference of Muslim Intelectual, Jakarta. http://eprints.ulm.ac.id/287/

Purwanto, P. (2017). Kontribusi Pembiayaan Perbankan Syariah Terhadap Disparitas Pendapatan di Indonesia Tahun 2015-2016. Cakrawala: Jurnal Studi Islam, 12(1). doi: http://doi.org/10.31603/cakrawala.v1 $2 \mathrm{i} 1.798$

Rifatunisa, R. (2019). Analisis Pengaruh Pendistribusian Dana Zakat Terhadap Mustahik Ditinjau Dengan Menggunakan Metode CIBEST. UNIVERSITAS ALMA ATA YOGYAKARTA.

Rini, N., Huda, N., \& Mardoni, Y. (2013). Peran dana zakat dalam mengurangi ketimpangan pendapatan dan kemiskinan. EKUITAS Jurnal Ekonomi Dan Keuangan, 17(1). doi: 
10.24034/j25485024.y2013.v17.i1.26 9

Rusny Istiqomah Sujono, A. P. N. (2017). The Influence Of Religiosity Toward Of The Muslim's Happiness With The Behavior Of Zakat, Infaq And Alms As Moderating Variables (Case Study At Laz Dompet Dhuafa Yogyakarta). 5th Southeast Asia International Islamic Philanthropy Conference, 527.

Safitri, A. (2019). Analisis Pengaruh Penyaluran Zakat terhadap Ketimpangan Pendapatan dan Tingkat Kemiskinan di Provinsi Aceh Periode 2007-2017: repository.ar-raniry.ac.id.

Salam, A., \& Risnawati, D. (2019). Analisis Zakat Produktif Terhadap Kesejahteraan Mustahik (Studi Pada Lembaga Amil Zakat Infaq Shodaqoh NU Yogyakarta). JESI (Jurnal Ekonomi Syariah Indonesia), 8(2), 96. https://doi.org/10.21927/jesi.2018.8(2 ). $96-106$

Sehrawat, M., \& Giri, A. (2018). The impact of financial development, economic growth, income inequality on poverty: evidence from India. Empirical Economics(55), 1585-1602. DOI: 10.1007/s00181-017-1321-7

Sriyana, J. (2014). Metode Regresi Data Panel. Cetakan Pertama: Yogyakarta: Ekonisia.
Stockhammer, E. (2010). Financialization and the global economy. Political Economy Research Institute Working Paper.

Widarjono, A. (2013a). Econometrics Introduction and Its Application.

Widarjono, A. (2013b). Ekonometrika: Pengantar dan aplikasinya, Ekonosia, Jakarta: Ekonesia.

Widiastuti, T. (2018). Optimization of Zakat fund management in regional Zakat institution. Humanities and Social Sciences Reviews, 6(2), 133-139. DOI: $10.18510 /$ hssr.2018.6217

Zaman, A. (2019). Islam's Gift: An Economy of Spiritual Development. American Journal of Economics and Sociology, 78(2), 443-491. DOI: 10.1111/ajes.12272 